\title{
Armenia-Azerbaijan Relations: Nagorno-Karabakh Conflict and its Peace Process
}

\author{
Nimra Irfan \\ MPHIL Scholar of International Relations \\ Greenwich University, Karachi Pakistan \\ nimra.irf10@gmail.com \\ Madiha Nawaz \\ MPHIL Scholar of International Relations \\ Greenwich University, Karachi Pakistan \\ Javeriaumaima@gmail.com \\ Prof. Dr. Syed Salahuddin Ahmed \\ Department of International Relations \\ Greenwich University, Karachi Pakistan \\ ahmadsyedsalahuddin@gmail.com
}

\begin{abstract}
The conflict that was started as a civil war in the Soviet Union turned into one of the longest, bloodiest post-Soviet conflicts. Armenia and Azerbaijan is fighting for Nagorno-Karabakh for over a century, have killed more than 300,000 people including military personnel and civilians. Geopolitical factors and ethnic differences between the two are the primary reasons of the dispute. Several mediating parties intervened and tried to bring a peaceful solution to the dispute, but due to the foreign interventions especially Russian and Turkish military support to the warring states have contributed to deteriorate the situation and also escalated the mistrust between Armenia and Azerbaijan. This research article examines the Armenia-Azerbaijan relations, historical background of Nagorno-Karabakh in detail along with the approach of international community towards it. It also evaluates its peace process and the performance of the main state and non-state actors. This article also has the timeline of clashes took place between Armenia and Azerbaijan over the occupation of Nagorno-Karabakh territory.
\end{abstract}




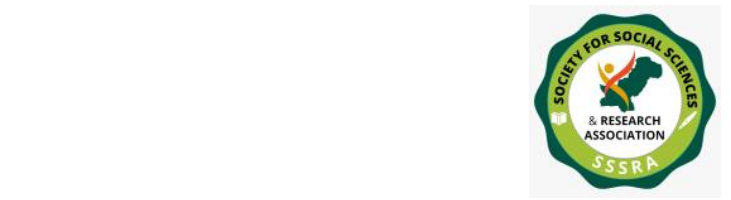

Pak. Journal of Int'L Affairs, Vol 4, Issue 1 (2021)

Armenia-Azerbaijan Relations ...

Keywords: Conflict, Armenia-Azerbaijan, mediation, geopolitics, Soviet Union, peace building.

\section{Introduction}

The conflict Nagorno-Karabakh is seen as a delayed post-soviet conflict. NagornoKarabakh is a disputed territory located in Lesser Caucuses Mountains. The parties that are fighting over it are Armenia and Azerbaijan since the collapse of Soviet Union 1991. It started three years later when both parties got their independence that makes it thirtyyear long conflict, killed around 300,000 and displaced a million within the region. Armenia and Azerbaijan has declared each other enemy states and does not have diplomatic relations.

(Askerov, 2020) Nagorno-Karabakh is recognized as a part of Azerbaijan territory, but it is totally controlled by Armenia since the beginning of 1990s. Armenia demanded independence of the territory because of its successful military control. In 1992, when Nagorno-Karabakh declared itself sovereign state which is not recognized by any country in the world, tensions intensified. Fights occurred and Armenian forces took over the territory and the nearby areas. The conflict is based on many claims from both sides about ethnic and historic importance of the region. The majority population claims that they own the exclusive right over the territory. Ethnic enmity is the old problem between Armenia and Azerbaijan because Armenia is a Christian majority and Azerbaijan is the Muslim majority country. Armenia believed that losing Karabakh will shift the ethnic balance towards Azerbaijan. Azerbaijan fears that giving up on this territory will be the beginning of the collapse of its own state.

This research article gives the overview about the Armenia-Azerbaijan relations, discusses in detail the history of Karabakh dispute to pinpoint the root causes of the conflict and also its geopolitical importance. Then the article analyses its peace process, behaviours of Armenia and Azerbaijan and the main mediators who are involved, specifically the role of Turkey and Russia who are seen as the secondary parties, trying to achieve their own political interests through this conflict.

\section{Armenia-Azerbaijan Relations}

Armenia and Azerbaijan both were the communist states under the rule of Soviet. Azerbaijan declared its independence on September 23, 1989, but eventually got independence in August 1991 after the collapse of Soviet Union. Similarly, Armenia became independent in December 1991. Both countries have no diplomatic relations and 


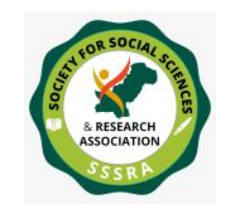

Pak. Journal of Int'L Affairs, Vol 4, Issue 1 (2021)

Armenia-Azerbaijan Relations ...

have declared each other enemy states due to their several religious, ethnic and geopolitical differences. Azerbaijan is a Muslim majority region, mainly Turks Muslims and Armenia is a Christian majority country. (Valigholizadeh \& Karimi, 2016) Azerbaijan is the important Muslim state in the Islamic world and Armenia is important in Christian world due to their historic ethnic identity. The hatred between the two states has been transferred from generations to generations. Both countries blame one another for becoming the victims of their policies against each other. The major bone of contention that stains their relations is the Nagorno-Karabakh territory. They have fought several small and large-scale wars for it since the Soviet rule.

(Sargsyan, 2003) In 1980 thousands of Armenians were forced to displace from Karabakh due to Azerbaijan's pressure. In 1988 first conflict broke out when Karabakh Armenians announced unification with Armenia Republic. From 1992-1994 several Armenian cities were bombarded by Azerbaijan forces killing hundreds of civilians, damaged hospitals, public properties and other infrastructures. Azerbaijan also blocked food and water of Armenians that led to many deaths. Ceasefire was established by Russia in 1994 which could not stop the conflict completely, but the situation remained in control for many years. This conflict also damaged the religious sites of both sides. Armenia claimed its holy churches were destroyed whereas Azerbaijan reported Armenian attacks destroyed several mosques. (Sofuoglu, 2020) The inhabitants of both countries also hate each other due to the genocide, massacre and massive killings. They developed the hatred at national level. After the ceasefire, peace talks were held time after time and Karabakh remained the main topic of concern, but both countries failed to reach to any mutually agreed conclusion. Ceasefire violations occurred several times, caused casualties from both sides. After the 1994, the most severe clash occurred is in 2016 known as 'four-day war' Azerbaijan was now much stronger, took its territories from Armenia's occupation. In April 6, 2016 when the war ended, Azerbaijan Defence Minister claimed that Armenia has violated the ceasefire 115 times. Also, they have attacked the Azerbaijani officers who were positioned there. Azerbaijan lost 31 military personnel and Armenia lost around 240.

(Human Rights Watch, 2021) The most recent conflict between the two broke out in September 7, 2020 initiated by Armenia. It killed more than five thousand military personnel and inhabitants from both sides and hundreds were wounded. In the beginning they rejected the third party interventions like United Nations and other foreign powers and just preferred fighting. Situation worsened when they started using shelling against each other and other dangerous weapons. In October, Russia established the ceasefire which was not accepted by both parties and the battle continued. Other ceasefire 


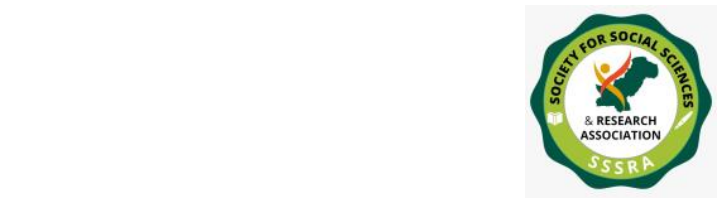

Pak. Journal of Int'L Affairs, Vol 4, Issue 1 (2021)

Armenia-Azerbaijan Relations ...

negotiations also took place by France and United States. By November conflict went against Armenia when Azerbaijan occupied the second largest region of Karabakh. (Kramer, 2021) Later in the same month, finally Russia established a ceasefire after three failed attempts which was agreed by Armenia and Azerbaijan ended the six-week war. The agreement permitted Azerbaijan to keep the territories they have captured and also forced Armenia to leave other parts excluding the capital city of Karabakh Stepanakert which would be under control by the peacekeepers of Russia. The locals of Armenia were not happy with the deal and protested. However, for now the ceasefire is observed from both sides. Russia deployed 2,000 peacekeeping troops on the Azerbaijan region to monitor the ceasefire.

\section{Historical Background of Nagorno-Karabakh Dispute}

Soviet leadership formed the autonomous Nagorno-Karabakh region during 1920s that had Armenian majority ethnic group within Azerbaijan territory. (Human Rights Watch, 2021) At that time, both concerned parties could not start a war against each other due to the Soviet leader Bolshevik's strong hold over them, but in 1988, the Armenians residing over there demanded to merge their region with Armenian Soviet Socialist Republic. Their demand was turned down by Soviet Union and Azerbaijan. It sparked up the conflict between Azerbaijan and Armenia. Both blamed each other for starting the aggressions. Around 100,000 refugees were exchanged, forced to leave the territory to avoid the physical fights. (Waal, 2003) Armenia had planned the revolt in Karabakh long before the actual conflict started. Weapons were distributed among Armenians living in Karabakh. A series of historic events flamed up the differences especially when Azerbaijanis were forced to leave the land. There were total 300,000 Azerbaijanis living there. This continued till 1990. Soviet Union's policies also played a role in the development of the conflict. Politician Arkady Volsky was appointed as a head of the Central Committee and Supreme Soviet of the Soviet Empire in Karabakh. Gorbachev Mikhail made him the leader of eight member committee for administration of Karabakh which was a violation of Azerbaijanis interests. This led to the protests against the Soviet government. On the other hand, Armenia saw this initiative in favour. Uncompromising attitude of the Azerbaijanis and the secret planning of Armenia were disclosed and thus a bloody war broke out between the two. Gorbachev administration left the region when a battle took place in Baku in 1990, caused 147 casualties and injured around 800 (Armenian Research Center , 1996).

(Inam-ul-Haque, 2020) In the period of 1989-1991, Karabakh conflict remained as a civil war which did not get much attention. The situation worsened after the collapse of Soviet Union in 1991. Azerbaijan and Armenia declared themselves independent. Their 


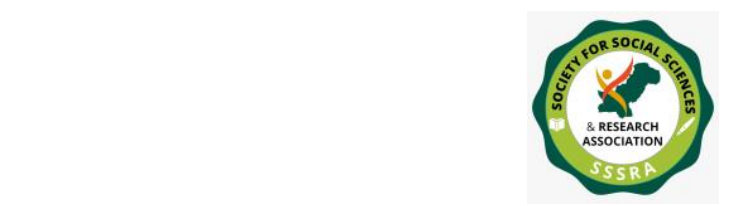

Armenia-Azerbaijan Relations ...

differences escalated when Nagorno-Karabakh declared itself independent through a referendum in 1992. Fights occurred and Armenia took control of the seven neighbouring areas of Azerbaijan with the help of Russia.

(Carley, 1998) The disintegration of Soviet Union gave freedom to both parties to use armaments and fight a full-fledged war. Till next year, Armenia occupied most of the region. The Lachin corridor was constructed by the Armenia that connected the Karabakh directly with its land. Armenian forces also captured the $20 \%$ region of Azerbaijan surrounding the Karabakh. The new international setup allowed Russia to intervene in the conflict and give its support to Armenia which weakened the Azerbaijan's stance. The fact that Russian troops are the reason behind the success of Armenia cannot be ignored. Khojaly massacre 1992 is the prominent example which was started by Russians and Armenians. It took 613 lives, wounded 487 and about 1,275 Azerbaijanis kept as hostages. (Askerov, 2020) Russia favoured Armenia because it never protested against Soviet's decision or mind Soviet forces now Russian forces on its lands. Russia supported Armenia in Nagorno-Karabakh conflict from the starting provided armaments and fuel. Russian has remained the active party in the conflict over the years. It serves as a main mediator which cannot be seen as fair or neutral because of its support to Armenians.

\section{Geographical Factors}

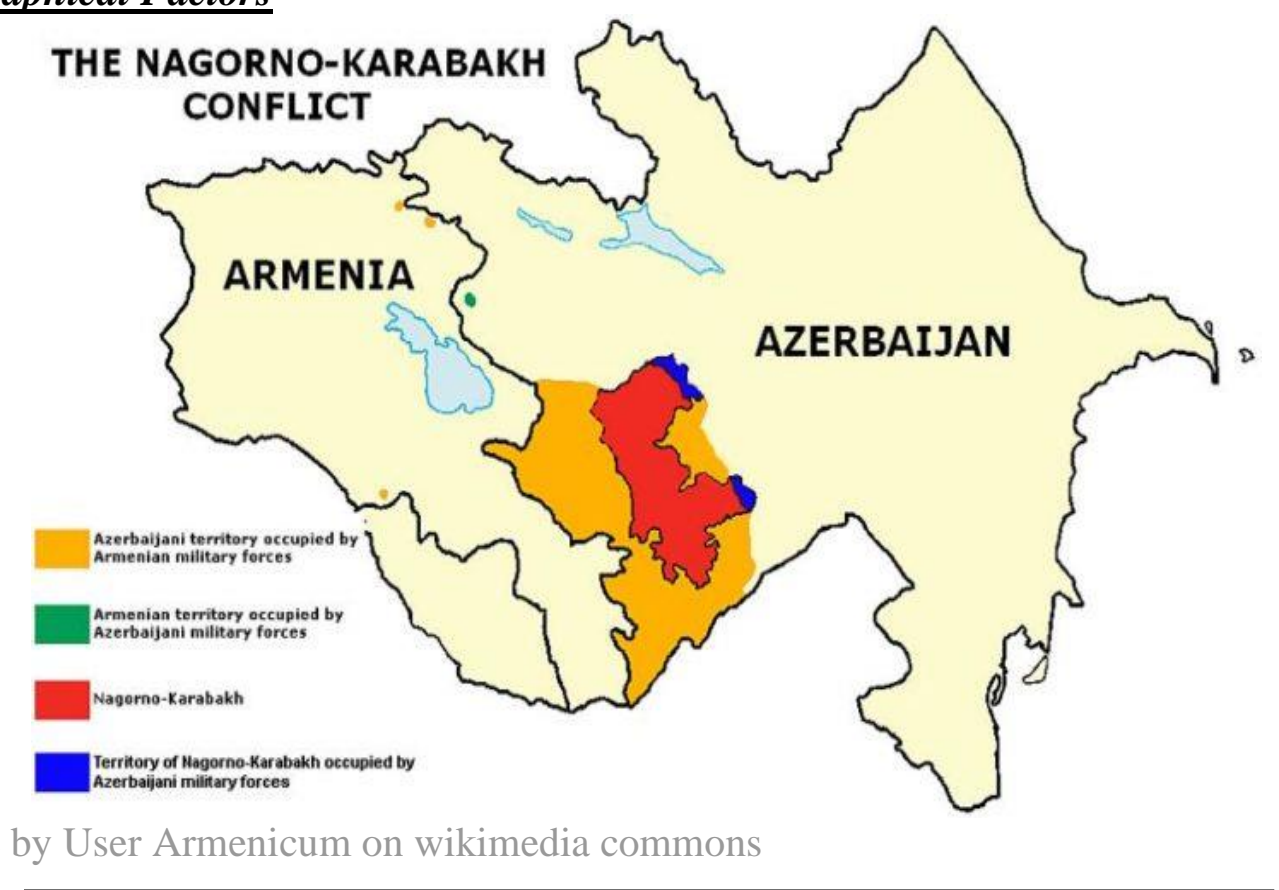

Image by User Armenicum on wikimedia commons 


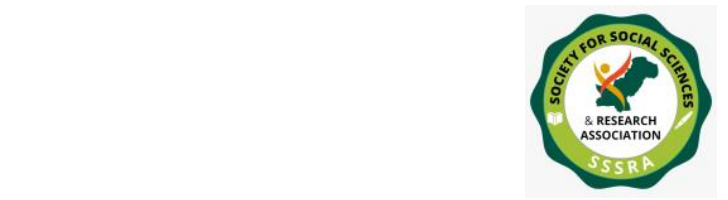

Pak. Journal of Int'L Affairs, Vol 4, Issue 1 (2021)

Armenia-Azerbaijan Relations ...

Nagorno-Karabakh is officially a south western territory of Azerbaijan, occupied the 1,700 square miles area, but currently the forces occupying 2,700 square miles claiming it a part of Karabakh. Due to majority Armenian population, Armenia considered it as its own part. Nagarno-Karabakh Republic declared itself de facto independent state from Azerbaijan rule since 1988. (Valigholizadeh \& Karimi, 2016) One of the main factors that started the conflict is Soviet Union itself. When it started occupying states, it divided the territories without considering their homogenous ethnic features. They were only separated by Soviet's political interests and concerns. Karabakh border problem emerged. (Wilson \& Parker, 2017) Geographically Karabakh is close to Armenia, separated by a small line, still Soviet declared Karabakh a part of Azerbaijan. This geographical issue makes the Karabakh dispute a national matter for both nations. Azerbaijan claims Karabakh as their own because the Karabakh is itself is an Azerbaijani name that explains that the territory is a part of Turks. On the contrary, Armenia believes that Karabakh is a home for Armenians since the Christian era. Its historic name is Artsakh.

Moreover, Karabakh is one of the main regions where population displacement took place under Soviet leadership. (Valigholizadeh \& Karimi, 2016) Before Soviet rule, Karabakh was a Muslim majority area, mostly Turks, but when Soviet Union occupied the lands it separated people into different, newly formed governmental units. This bad displacement still exists in some states. Caucasia was important region for Soviet for establishing its military bases. It shifted Armenians there to reduce the influence of Turks and Iranians because Soviet believed that Armenians will protect its interests. In that time 18,000 Armenians shifted in Karabakh in 1825 forced Turks to leave the place through genocide. 35,000 Muslims migrated in response and thus the whole geographical situation of the region changed. Apart from these factors, Karabakh also holds economic importance for both parties. It has proper climate, large grass fields, store mines and several rivers linked with Azerbaijan. Therefore, the territory is important for Azerbaijan economy. If it would be occupied by some other state, indeed it will affect Azerbaijan economic system. For Armenia, there are rivers in Karabakh that connects with Armenia. They are a source of water for Armenia. Armenia's economic concerns rose when it was isolated through economic sanctions by Azerbaijan and Turkey. Blockades on energy transferral projects and necessary transport triggered the economic depression in the country. These sanctions can also spark up the economic crisis so Karabakh is important for Armenia as it provide a route to Iran. 


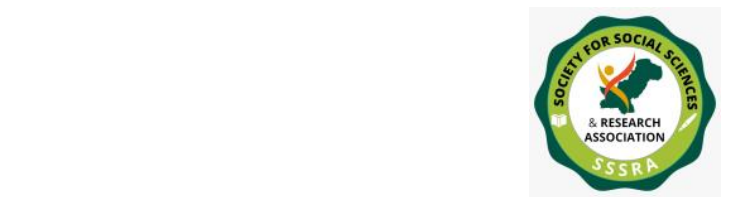

Pak. Journal of Int'L Affairs, Vol 4, Issue 1 (2021)

Armenia-Azerbaijan Relations ...

\section{Timeline of Armenia-Azerbaijan conflicts over Nagorno-Karabakh}

1918 - After Soviet Revolution, Armenia and Azerbaijan got independence. Azerbaijan tried to take over Nagorno-Karabakh, but it stopped by local Armenians.

1920 - Armenia came under Soviet rule. Azerbaijan took control of Karabakh and other three territories of Armenia.

1988 - First ever Nagorno-Karabakh war took place. Inhabitants of Karabakh demanded to unify with Armenia. Azerbaijan turned down the demands. As a result riots broke out between the two parties.

January 1989 - Soviet established its direct government in Karabakh territory. Clashes between Armenia and Azerbaijan continued. Three Soviet troops were killed while securing the Armenians from Azerbaijanis mobs.

December 1989 - Both parties blocked each other's shipments. The on and off of these blockades still carry out in present times.

1990 - Azerbaijan declared itself independent under Soviet leadership and allowed the military actions against Armenians whenever it's necessary. Riots become frequent on the borders of Karabakh.

1991 - Due to the expected Armenian guerrillas, Soviet expelled 10,000 Armenians from Azerbaijan.

September 1991 - Leaders of Armenia in Karabakh declared themselves independent from Soviet Union.

1992 - Large scales fights broke out between Azerbaijan and Armenia. Azerbaijan attacks the parts of Karabakh including some regions of Armenia. Armenia took control of Liachin and constructed a bridge between Karabakh and Armenia by May 1992.

1993 - Armenia occupied Jebrayl, Fizuli and Kubati regions surrounding the Karabakh territory.

May 1994 - Ceasefire was established by Russia that ended the four-year war between both parties over Nagorno-Karabakh. Secretive Turkish support to Azerbaijan compelled the leaders of Karabakh to violate the ceasefire.

January 1995 - Azerbaijan's attacks continued around Karabakh despite the ceasefire line.

April 1995 - Red Cross reported that breach of ceasefire had escalated. 1996 - Series of talks were held to settle down the differences.

Mar 1997 - Armenia released a statement accusing Azerbaijan constructing weapons and planning military actions to capture Karabakh territory. The blame was refused by Azerbaijan.

April 1997 - Fights started in the third week of April. Both parties accused each other for initiating the conflict. Russia reported 32 prominent cease-fire violations. 


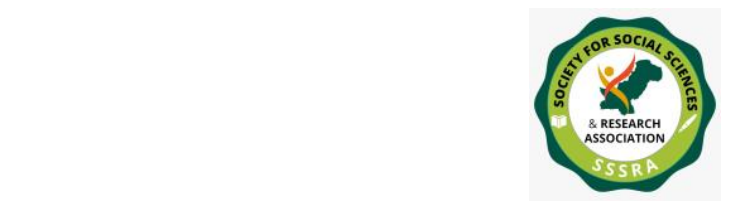

Armenia-Azerbaijan Relations ...

August 1997 - Russia and Armenia signed a strategic pact resulted in sending 12,000 troops to Armenia and provided border guards to protect Armenian borders.

2004 - Armenian officer Gurgen Margaryan was killed by Azerbaijan officer Ramil Safarov during NATO training triggered the mistrust between Armenia and Azerbaijan.

2007 - Azerbaijan took advantage of Armenia's internal instability due to conflicted presidential elections by launching attacks Martakert in Karabakh that killed several people.

2016 - Azerbaijan started offensive which was the biggest since the last fights in 1994. 4day war broke out that included heavy drone attacks and bombs from both sides resulted hundreds of casualties. Azerbaijan occupied southern part of line of control.

2017 - Situation worsened when Azerbaijan launched air strikes.

2020 - Azerbaijan forces tried to cross Tavush, a village in Armenia that killed 4 officers. It triggers the pre-war protests in Azerbaijan.

July-August 2020 - Turkey announced its full support to Azerbaijan and provided fighter planes and other equipment.

September 2020 - Full-scale war started by Azerbaijan violating the ceasefire in Karabakh.

October 2020 - 21 days of continuous fighting, the presidents of both parties agreed to meet. October 20, ceasefire agreement offered by United States was only observed for few minutes when Azerbaijani forces violated. In the end of the month, Azerbaijan used worldwide forbidden chemical weapons against Armenia caused environmental devastation.

November 2020 - Russia established a ceasefire line and deployed its peacekeeping troops in the battlefield of Nagorno-Karabakh including the Liachin corridor and LoC. (Source: Armenian Research Center 1996, Minority at Risk Project 2004, AFP 2020)

\section{Conflict Resolution Process of Nagorno-Karabakh}

Analysts comment that the failure of the peace process of Karabakh conflict is not because of the ineffectiveness of non-state actors, but it is the interests of the some states that are also escalating the suspicion between Armenia and Azerbaijan. (Khalid, 2008) Several mediators are involved in the conflict resolution of Nagorno-Karabakh and tried to settle the dispute over the years. They made effort to facilitate peaceful negotiations between Azerbaijan and Armenia. The very first attempts made by Russia, Turkey, Kazakhstan, Iran and France. Russia established the first ceasefire in 1994 and since then situation is not much changed and violations of the ceasefire occurred many times. The peaceful talks proved to be useful only for short period of time, but tension between the two parties always remained. Conference on Security and Cooperation in Europe (CSCE) established the Minsk Group co-chaired by three big powers; Russia, United States and 


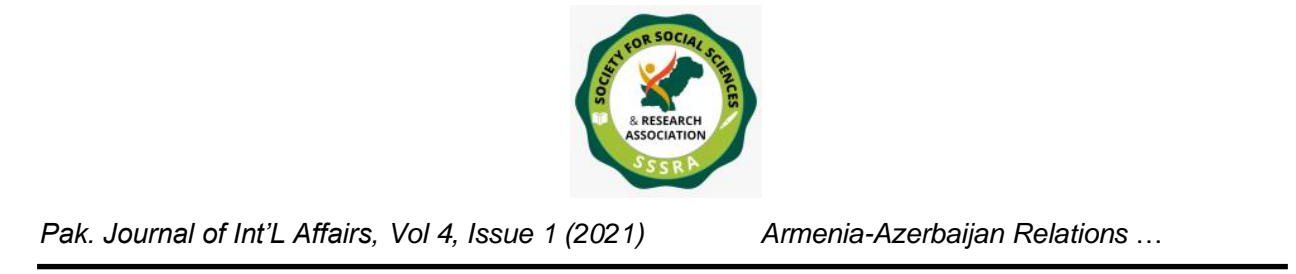

France, then United Nations also offered resolutions to the concerned parties including the European Union and other small and big civil societies.

\section{Main Actors involved; \\ 1. CSCE Minsk Group}

Minsk Group is the leading actor in the Karabakh conflict resolution efforts established by Conference on Security and Cooperation in Europe in 1992. (Now it is called Organization for Security and Cooperation in Europe). (OSCE) Members of the Minsk Group are Azerbaijan, Armenia, Sweden, Turkey, Russia, Germany, Italy, United States, Belarus, France and Czech Republic. The main purpose of its creation is to hold a conference in Minsk and facilitates negotiations between Azerbaijan and Armenia. Though the conference never held, still Minsk Group is the special political body in the history of the peace process of Karabakh. The three main objectives of it are; to look for suitable framework to solve the dispute, to establish a ceasefire and arrange a conference, to promote the peaceful resolution through peacekeeping forces.

(Waal, 2010) Negotiations could not be conducted in the Minsk context because Azerbaijan refused to take Karabakh as a separate party and said that talks can only be possible between Azerbaijan and Armenia. On the other hand, Armenia stressed upon that it is not supporting Karabakh's independence. It can participate in negotiations but not for the independence. However till 1997, Stepanakart, the capital of Karabakh became a third party in peace talks and it was agreed that nothing can be decided without the involvement of these three main participants. In 2001, representatives of Azerbaijan, Armenia, France, Russia and United States organized a meeting in Paris. The concerned parties did not agree to follow the outcome of the meeting. Similarly, in 2002, Armenian and Azerbaijani leaders met under the Minsk Group. This meeting also cannot bring any noticeable changes.

(Welt \& Bowen, 2021) In 2007, it gave main principles known as Madrid Principles which will be observed by the Minsk Group for the conflict resolution. Those principles are;

- $\quad$ Armenia would leave the surrounding regions of Karabakh and give them back to Azerbaijan.

- $\quad$ Giving interim status to Nagorno-Karabakh which would guarantee its security and a right of self-governance.

- $\quad$ Establishing a corridor connecting Armenia to Karabakh.

- $\quad$ Deciding the future of Karabakh through popular vote.

- $\quad$ Providing freedom to displaced people to go back to their previous homes.

- $\quad$ Peace keeping operations will carry out. 


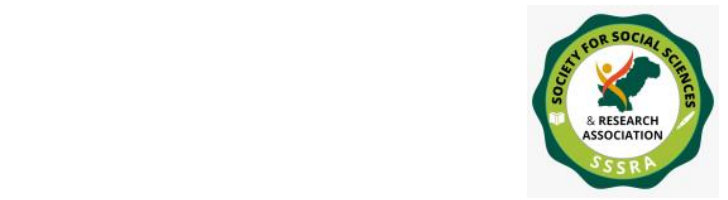

Pak. Journal of Int'L Affairs, Vol 4, Issue 1 (2021)

Armenia-Azerbaijan Relations ...

Azerbaijan and Armenia carried out peace talks under those principles, but they failed to come to any mutually agreed solution. Armenia and Karabakh leaders wanted the separation of Karabakh from Azerbaijan control whether as an independent state or linked with Armenia. Azerbaijan claimed its territorial integrity and sovereignty over Karabakh and its neighbouring regions. It threatened that if negotiations would not help in achieving its objectives then it would use force.

\section{United Nations}

The conflicts between Armenia and Azerbaijan increased when the collapse of the Soviet Union was near. (Kramer, 2021) With the help of Russian Federation, Armenia occupied seven neighbouring regions of Karabakh. The increasing clashes brought United Nations attention to the dispute. The Security Council adopted four resolutions in 1993. Initially it demanded the immediate withdrawal of troops of Armenia from those seven districts that are outside the Karabakh declaring that those are Azerbaijan's territory legally. It was the Azerbaijan who took the case to the Security Council because it was not satisfied with the performance of Minsk Group. (US Department of State, Archive) The resolutions (822, 853, 874, and 884) were adopted in 1993 which was against Armenia. One of the main reasons of its failure is that it ignored the intervention of the external forces such as Russia. The Resolution 822 demanded the withdrawal of Armenian forces from the territory of Azerbaijan, Kelbadjar. The Resolution 853 demanded the freedom of Agdam territory. Resolution 874 demanded the withdrawal of Armenian forces from its recent occupations of Azerbaijan districts and the last resolution 884 was about accusing the violations of cease-fire line established in 1994.

Due to favouring the Azerbaijan's interests, Armenia completely rejected all the resolutions. The importance of Minsk Group is also elucidated in SC resolutions few times, but these resolutions were never executed. (Haddou, 2020) SC itself never tried to implement its resolutions. UN charter's article 25 says that member states have to follow the UN resolutions or else sanctions will be imposed on them mentioned in the Article 41. Armenia never faced any sort of sanctions. Different explanations were given regarding the UN behaviour. They say that Armenia demanded the right of selfdetermination for the residents of Karabakh. But international law and UN only recognized the self-determination right of colonized territories. And Karabakh was legally Azerbaijani state. And UN cannot violate the territorial integrity of the sovereign country. Thus the original nature of the dispute weakens the peace building process of United Nations. Since then, UN played little or no part in the Karabakh conflict and remained mute. 


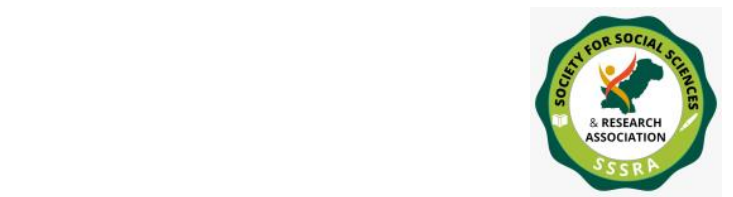

Pak. Journal of Int'L Affairs, Vol 4, Issue 1 (2021)

Armenia-Azerbaijan Relations ...

\section{European Union}

The intervention of European Union in Karabakh conflict is because of its European Neighbourhood policy and its Eastern Partnership policy which says the EU would participate in the stability of the neighbours of Europe. (Klever, 2013) EU supported the efforts of Minsk Group, but so far its involvement does not bring progressive development to the conflict. France is co-chairing the Minsk Group, but here it is not representing EU. The organization also favours the peaceful settlement of NagornoKarabakh dispute. EU tried to help settle down the dispute, but few of its policies were turned down due to differences between Azerbaijan and Armenia. Other reasons that made its stance weak were that Armenia and Azerbaijan never asked for its mediation. Armenia did not want to offend Russia by letting EU involved in the matter and Azerbaijan condemned its neutral policies. In the year 2005, when EU brought both parties to sign the agreement which included several sectors for mutual development while ignoring Karabakh conflict. Azerbaijan forced EU to recognize Karabakh district and other seven districts as a part of Azerbaijan's state. EU was not ready for it that further annoyed Azerbaijan.

(Popescu, 2020) In 2003 European Union appointed its two special representatives at South Caucasus Heikki Talvitie and Peter Semneby to stronger the influence of the organisation in that part. It wanted to execute confidence building projects and some aid for the peaceful settlement of conflicts in South Caucasus. They proved to be helpful in Abkhazia and South Ossetia conflict, but not with Karabakh conflict. By 2007, Azerbaijan became doubtful about the attitude of international community in the resolution of Karabakh conflict. This made Azerbaijan to increase its military preparations and completely refuse for any kind of diplomatic negotiations. Azerbaijan lost its full trust on EU when in 2008 most of the European states recognized the independence of Kosovo from Serbia. It believed that this decision is a hindrance in the Karabakh peace process. All of these factors compelled Azerbaijan to use military means to settle down the dispute. (Grgic \& Knoll-Tudor, 2020) What EU can do now? The options available for EU is to force Azerbaijan and Armenia to follow Madrid Principles propose by Minsk Group. It can also offer peacekeeping operations and other funds for the reconstructions of the post-clashes damages, but it would only be possible when Armenia and Azerbaijan give their consent. And this would not happen. Both states are not ready for EU's mediation. So this scenario makes the EU in this dispute an ineffective organization. 


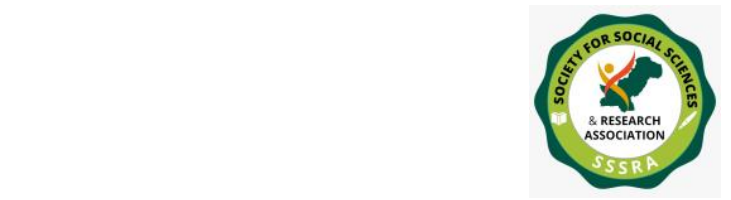

Pak. Journal of Int'L Affairs, Vol 4, Issue 1 (2021)

Armenia-Azerbaijan Relations ...

\section{Council of Europe}

The organisation is not directly involved in the Karabakh conflict, but it always supported the decisions taken by the Minsk Group. Also, it condemned the declaration of Karabakh when it called itself sovereign region. In 1991, Parliamentary Assembly of Council of Europe (PACE) announced its support to Minsk Group and offered that it would be ready for all kind of help for the Karabakh peace process. Similarly, in 2001, it gave the same proposition. In 2005, PACE sent its own representatives to support the UN resolutions and stop violence and illegal occupation of zones. In later years, it tried to stop Karabakh from holding elections. In the most recent clashes over Karabakh conflict in 2020, the Secretary General of the Council addressed the Azerbaijan and Armenia administration to avoid hostilities against innocent civilians and look for peaceful solutions as soon as possible. The council is with Minsk Group's decision (Strasbourg, 2020).

\section{Other civil Societies}

There are several other civil societies based in Europe and South Caucasus worked for the peace of the Nagorno-Karabakh conflict. The main is the European Partnership for the Peaceful Settlement of Nagorno-Karabakh (EPNK) which started series of projects with their South Caucasian partners to support the affected segments of the territory from the conflict and also worked with local media to strengthen the idea of peaceful settlement. Other civil societies that are located in South Caucasus; Stepanakart Press Club Karabakh, Society for Humanitarian Research Azerbaijan, Yerevan Press Club Armenia, International and comparative law Centre Armenia, Peace Dialogue Armenia, Eurasia Partnership Azerbaijan and Armenia, Internews Azerbaijan and Internews Armenia, Public Council for Foreign and Security Policy Nagorno-Karabakh, Helsinki Citizens' Assembly, Armenia and Azerbaijan and Helsinki Intiative-92 (HI-92), Nagorno-Karabakh are altogether working for peace building efforts in the region (Klever, 2013).

\section{Role of Russia}

Russia's involvement in the conflict is inevitable because Armenia and Azerbaijan were former Soviet's states. Instead of neutral policy, Russia sided with Armenia and helped it with military support. (Khalid, 2008) It has been said that Armenia and Azerbaijan are the primary parties of the conflict and Russia is the secondary player and the main mediator. Russia has also co-chaired Minsk Group which is a very important organization that is trying to settle the dispute. Russia's involvement is so prominent in the Karabakh conflict that it can intensify or reduce the tension according to its own political interests. It plays a significant role in deciding the progress of the conflict. (Boyajian, 2019) Moreover, Armenia's security is completely in the hands of Russia. Both countries need 


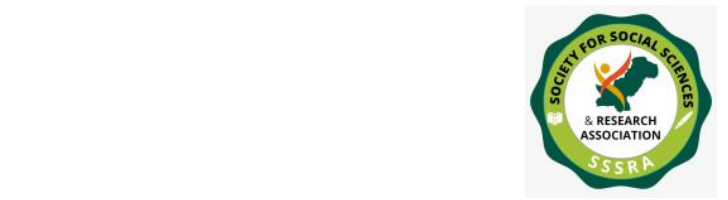

Pak. Journal of Int'L Affairs, Vol 4, Issue 1 (2021)

Armenia-Azerbaijan Relations ...

each other for their own objectives. This scenario will not change until Armenia decides to change its policy about resolving the conflict. Analysts argue that Azerbaijan would have sorted out everything in 1993 if Russia wouldn't have backed up Armenia militarily. Baku needed to convince Moscow to stop intervening that never happened because Russia had its own interests in Armenia due to its geopolitical significance in Kremlin. And in 2008 when Russia had to remove its troops from Georgia, Armenia was the only country to maintain its legal influence in South Caucasian region. Russia and Armenia became strong partners. Armenia was the only friend of Russia in South Caucasus therefore Kremlin never hesitated to offer military support to Armenia in occupying Azerbaijani districts. The problem was that Russia introduced itself in the Karabakh conflict as mediator, but siding Armenia openly made its position partial and biased. Azerbaijan mistrusted Moscow's mediation in Minsk Group when it was disclosed that Russia had donated short-range ballistic missiles and fighter jets to Armenia in 1997. This angered Baku and made it realize that Armenia's claim about the peaceful settlement is false and baseless. (Friedman, 2008) The truth is that Russia's intervention is vital as it is reflecting Russia's objectives in the South Caucasian region. It wants the entire area in its control and this is one of the main reasons why Nagorno-Karabakh conflict remains unsolved. Ever since President Putin came in power in 2000 Russian foreign policy is to revive the influence of Russia over the former Soviet states including South Caucasus to counter the EU and NATO positions.

Relations between Azerbaijan and Russia remained unfriendly. Azerbaijan developed its energy routes in the $20^{\text {th }}$ century without the interference of Russia. However, presently, the situation seems to change. Armenia started becoming sceptical about Russia's sincerity towards them when it sold weapons to Azerbaijan. (Nazaretyan, 2021) Around $80 \%$ arms of Azerbaijan imported by Russia from $2009-2013$ and $31 \%$ till 2019. This arms distribution to both Armenia and Azerbaijan will lead to another round of hostile clashes which would eventually benefit Russia. It can increase its influence in the region by imposing condition to both of the disputed parties. (Global Security, 2013) Azerbaijani big politicians have connections with Moscow which are not publicised. They also have relations with Azerbaijani nationals living in Moscow. Russian ambassador Vasily Istratov to Baku disclosed that he trained several rich Azerbaijanis when he used to be a professor at Moscow State University.

Apart all of these partialities of Russia, still the country proved its mediation somewhat useful to Nagorno-Karabakh conflict. Russia was the first country who managed to stop the clashes between Azerbaijan and Armenia by establishing a ceasefire in 1994 which was agreed by both parties. However, the fact that it was violated several 


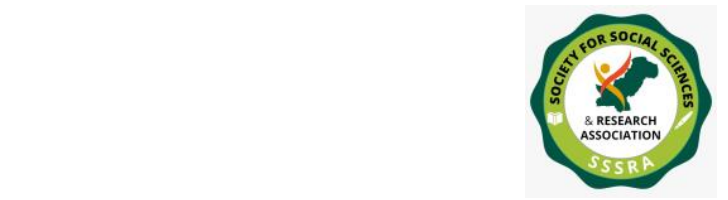

Armenia-Azerbaijan Relations ...

times in later years cannot be ignored, but Russia reduced the tension. Similarly, in the recent war that initiated in October 2020 in which both parties used heavy and environmentally dangerous weapons against each other, Russia once again intervene and successfully drew the ceasefire and terminated the war immediately. It also deployed its peacekeeping forces at the ceasefire to monitor two warring countries. Russia also stopped Turkish presence by saying that no Turkish forces will be allowed at the ceasefire. The risks factors are there that peace deal will be expired in next five years which will allow Armenia and Azerbaijan to resume their positions.

\section{Role of Turkey}

Turkey is the main military supplier of Azerbaijan. Ethno-linguistic similarities brought two countries closer. Azerbaijanis speak Turkic language and most of the population is Muslim. Both nations have good economic and political ties. First former Azerbaijan president Heydev Aliyev in 1990s then president of Turkey Tayyib Erdogan described their relations as "one nation, two states." (Kreddie, 2020) On the other hand, Turkey has tensed historic relations with Armenia. Armenia accused Turkey for killing 1.5 million Armenians in the genocide during ottoman rule. Turkey however denies those accusations. In the early 2000s both sides made effort to start a formal diplomatic relations which though failed. The reasons for the failure were the Turkish demands from Armenia to withdraw their troops from Azerbaijan's territories including the NagornoKarabakh. (Nazaretyan, 2021) Turkish military supplies increased to Azerbaijan in last ten years making Turkey the third biggest supplier next to Israel and Russia. Azerbaijan became stronger as compared to its enemy state. In July-August 2020 Karabakh conflict Turkey provided F-16 fighter jets, special Turkish made drones and other armaments to Ganja, city of Azerbaijan. Moreover, Armenia blamed Turkey that it sent its own soldiers to help Azerbaijan which later on denied by Turkey and Azerbaijan itself.

(Gafarli, Anapiosya, \& Öztarsu, 2016) Turkey has its own interests for supporting Azerbaijan. Azerbaijan is important for Turkey's energy security and Azerbaijan is the main investor for Turkey. The state oil company of Azerbaijan was the biggest outside investor by 2020. Turkey wants to increase its influence regionally and also claims that the co-chair members of the Minsk Group are ineffective in the Karabakh conflict resolution. According to Turkey it is not an efficient institute. It's been thirty years and the Minsk Group is unable to do its job. (Isachenko, 2020) Additionally, Russia, United States and France are the three main parties in the settlement of Karabakh conflict, Turkey wants to participate too to show its regional importance. In 2010 Ankara and Baku signed an agreement on strategic partnership and mutual assistance which stated that both parties will support each other during the time of conflict. This agreement 


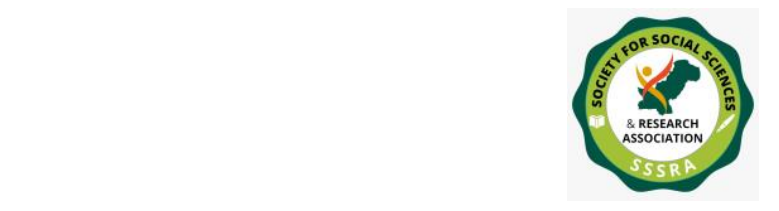

Pak. Journal of Int'L Affairs, Vol 4, Issue 1 (2021)

Armenia-Azerbaijan Relations ...

allows Turkey to intervene in Karabakh conflict. Same type of agreement was signed between Armenia and Russia. It is also argued that Azerbaijan signed the agreement because of its disappointment towards the Minsk Group. Turkey's objectives are to go beyond the Armenia-Azerbaijan clashes. Turkish Minister Hulusi Akar announced that Turkey should have a say in Middle East, Caucasus and the Balkan regional issues. The country wants the world to realise that it is another great power beside Russia and United States.

(Gabuev, 2020) In the November-October 2020 clash between Azerbaijan and Armenia reports have said that Turkey supplied armaments and drones to Azerbaijan and even trained the country military personnel though Ankara denied those allegations. However President Erdogan announced its full diplomatic support to Azerbaijan. Azerbaijan victory explains the Turkish role. But Turkey continues and will continue to intervene in South Caucasus matters. Armenian Prime Minister Pashinyan recently talked about Turkey's imperialist desires that are expected to reach till Vienna through Syria, Iraq and then will take over Mediterranean and Armenia. He further said that Turkey wants Armenian genocide that's why it is trying to intervene in Armenia. Turkish militarization cannot be ignored in that part. European Union takes Turkey as a threatening partner now.

\section{Conclusion}

The whole of the peace process of Nagorno-Karabakh does not promise any long term solution, but only relaxes the timely clashes between Azerbaijan and Armenia. Due to the international pressures and disappointments, Azerbaijan reserves the right to use war as a mean to free its territory from Armenia especially when it already tried to solve through peaceful methods. Black garden in the mountains has become an international battlefield after Syria where regional and world powers are fighting for their own political objectives. The dispute is mainly between Azerbaijan and Armenia who are claiming the ownership of the territory, but Russian and Turkish support to their respective allies play a major role in increasing and reducing the tension between the two according to their changing moods and interests. In fact, some politics observers call the Nagorno-Karabakh clashes as proxy wars of Russia and Turkey. Foreign power interventions in the disguise of mediations are hindering its peace process. Their mediating efforts are dubious that whether they are trying to solve the problem or using this as an excuse to interfere into the politics of South Caucasus region. Russia is actually ruining the whole peace process by staying as a main mediator. It should not be a part of mediation team when it is providing military aid to Armenia since the collapse of Soviet Union. It is also playing a double role, not only supporting Armenia but also sold 


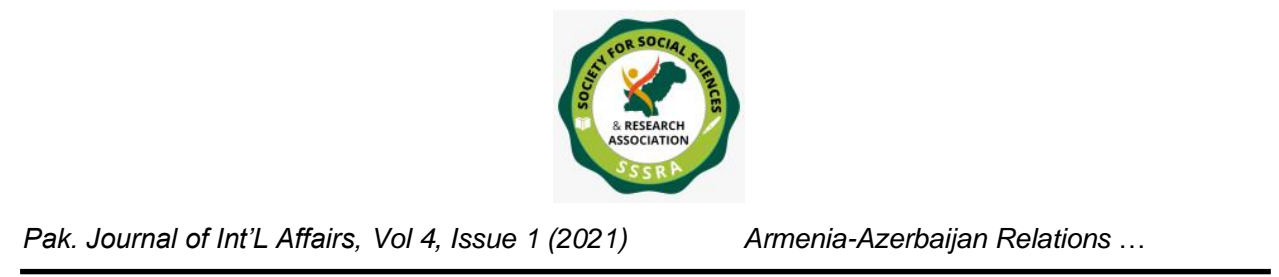

weapons to Azerbaijan secretly. Russia is also not in favour of resolving the conflict because it will reduce the influence of Moscow in the region. Russian support to Azerbaijan has offended the Armenians. Anti-Russian sentiments have risen in Armenia. This will force the country to rethink about its foreign policy towards Russia and this will also cause Armenia not to listen to its proposals regarding the conflict resolution in future. Russia is however able to stop the recent clash between two parties, but aggressions among Armenians and Azerbaijanis are alive and very fresh. Riots can enflamed any time.

Similarly, in the context of international organizations and other prominent non state actors who are incorporated in the matter, we can say that whenever a big power or powers are involved in any conflict, the large international organizations like United Nations are silenced or become ineffective. This evidently explains that these institutions are merely a puppet of the global powers. They would not be much of help because they are fully controlled by them.

The long term solution is impossible in this situation until Azerbaijan and Armenia get ready for table talk and be flexible in their foreign policies against each other. But on the other hand, the ethnic differences among the civilians from both sides will never allow them to accept each other as friendly states. Concerned parties and mediators should look for ground realities and the root causes instead of looking at the conflict from its face value. The on-going situation of 'no war - no peace' is not going to remain forever. The clashes are likely to occur. 


\section{References}

AFP. (2020, September 29). Azerbaijan-Armenia war: A timeline of the NagornoKarabakh dispute. Retrieved June 07, 2021, from Geo News: https://www.geo.tv/latest/310597-azerbaijan

Armenian Research Center . (1996, April 3). Fact Sheet Nagarno-Karabakh, University of Michigan-Dearborn. Retrieved June 07, 2021, from Karabakhfacts.com: https://karabakhfacts.com/fact-sheet-nagorno-karabagh-university-of-michigandearborn/\#more-753

Askerov, A. (2020). Nagorno-Karabakh Conflict - The Beginning of the Soviet End. In S. B. Ali Askerov, Post-Soviet Conflicts: The Thirty Years' Crisis (pp. 55-82). United Kingdom : Lexington Books .

Boyajian, D. (2019, Feb 05). Why Russia Needs Armenia and Vice Versa. Retrieved June 06, 2021, from The Armenian Weekly : https://armenianweekly.com/2019/02/05/why-russia-needs-armenia-and-viceversa/

Carley, P. (1998). Nagarno-Karabakh Conflict: Searching for Solution. Washington: United States Institute of Peace.

Friedman, G. (2008, August 12). The Russo-Georgian War and the Balance of Power. Retrieved May 29, 2021, from Startfor: https://worldview.stratfor.com/article/russo-georgian-war-and-balance-power

Gabuev, A. (2020, November 20). Viewpoint: Russia and Turkey - unlikely victors of Karabakh conflict. BBC News.

Gafarli, O., Anapiosya, A., \& Öztarsu, K. C. (2016). The Role of Global and Regional Actors in the South Caucasus. Journal of Conflict Transformation, 1-36.

Global Security. (2013, November 14). Azerbaijan - Russia Relations. Retrieved from Global Security: https://www.globalsecurity.org/military/world/azerbaijan/foreign-relationsrussia.htm 


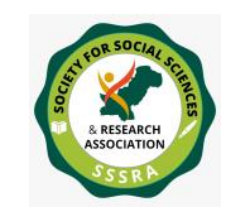

Pak. Journal of Int'L Affairs, Vol 4, Issue 1 (2021)

Armenia-Azerbaijan Relations ...

Grgic, B., \& Knoll-Tudor, B. (2020, December 18). What role for the EU in post-war Karabakh? Retrieved from Euractiv https://www.euractiv.com/section/azerbaijan/opinion/what-role-for-the-eu-inpost-war-karabakh/

Haddou, R. A. (2020, December 2). Nagorno-Karabakh: origins, peace process and awakening of a "frozen conflict". Retrieved from EU-Logos Athena: https://www.eu-logos.org/2020/12/02/nagorno-karabakh-origins-peace-processand-awakening-of-a-frozen-conflict/

Human Rights Watch. (2021, May 12). Nagorno-Karabakh . Retrieved from Global Conflict Tracker : https://www.cfr.org/global-conflict-tracker/conflict/nagornokarabakh-conflict

Inam-ul-Haque. (2020, October 15). Geopolitics of Nagorno-Karabakh. Retrieved May 29, 2021, from The Express Tribune https://tribune.com.pk/story/2268372/geopolitics-of-nagorno-karabakh

Isachenko, D. (2020, November). Turkey-Russia Partnership in the War over NagornoKarabakh. Retrieved from German Institute for International and Security Affairs: https://www.swp-berlin.org/10.18449/2020C53/

Khalid, I. (2008). Nagorno-Karabakh Conflict. Journal of Political Science, 25-44.

Klever, E. (2013). The Nagorno-Karabakh conflict between Armenia and Azerbaijan: An overview of the current situation. Brussels : European Movement International .

Kramer, A. E. (2021, January 29). Armenia and Azerbaijan: What Sparked War and Will Peace Prevail? The New York Times .

Kreddie, P. (2020, October 30). What's Turkey's role in the Nagorno-Karabakh conflict? Al-Jazeera .

Minorities at Risk Project, Chronology for Armenians in Azerbaijan, 2004, available at: https://www.refworld.org/docid/469f3866c.html

Nazaretyan, H. (2021, Feb 17). Arms Supplies to Armenia and Azerbaijan. Retrieved May 29, 2021, from EVN Report : https://www.evnreport.com/spotlightkarabakh/arms-supplies-to-armenia-and-azerbaijan

OSCE. (n.d.). Who we are. Retrieved from Organization for Security and Cooperation in Europe:htps://wwwosceorg/minsk group/108306 
Popescu, N. (2020, October 13). How the EU became marginalised in NagornoKarabakh. Retrieved from European Council on Foriegn Relations: https://ecfr.eu/article/commentary_how_europe_became_marginalised_in_nagorn o_karabakh/

Sargsyan, I. (2003). International Mediation in Theory and Practice: Lessons of Nagorno-Karabakh . Armenia: Armenian Center for National and International Studies.

Sofuoglu, M. (2020, July 16). Why Azerbaijanis and Armenians have been fighting for so long? TRT World.

Strasbourg. (2020, September 27). Nagorno-Karabakh: Secretary General calls for immediate end to hostilities. Retrieved from Council of Europe : https://www.coe.int/en/web/portal/-/nagorno-karabakh-secretary-general-callsfor-immediate-end-to-hostilities

US Department of State, Archive. (n.d.). 1993 UN Security Council Resolutions on Nagorno-Karabakh. Retrieved from US Department of State: https://20012009.state.gov/p/eur/rls/or/13508.htm

Valigholizadeh, A., \& Karimi, M. (2016). Geographical explanation of the factors disputed in the Karabakh geopolitical crisis. Journal of Eurasian Studies, 7(2), 172-180.

Waal, T. D. (2003). Black Garden . New York: New York University Press.

Waal, T. D. (2010, August 01). Remaking the Nagorno-Karabakh Peace Process. Retrieved June 07, 2021, from Carnegie Endowment for International Peace : https://carnegieendowment.org/2010/08/01/remaking-nagorno-karabakh-peaceprocess/31dh

Welt, C., \& Bowen, A. S. (2021). Azerbaijan and Armenia: The Nagorno-Karabakh Conflict. Washington D.C : Congressional Research Service .

Wilson, J., \& Parker, D. (2017, Feb 2016). Nagorno-Karabakh . Retrieved May 29, 2021, from Geohistory: https://geohistory.today/nagorno-karabakh/ 